University

\title{
THE TEACHING AND LEARNING OF L2 ENGLISH INTONATION IN A DISTANCE EDUCATION ENVIRONMENT: TL_TOBI VS. THE TRADITIONAL MODELS
}

\section{INTRODUCTION}

\subsection{Intonation Models and the Teaching of Intonation}

For more than eighty years, most of the training materials for the teaching of English intonation to L2 students have been designed within the tenets of the British School of intonational description, which started with the works of Palmer (1922), Kingdon (1958) and Crystal (1969) and developed in the studies of Couper-Kuhlen (1986), Cruttenden (1986), Gimson (1980), O'Connor and Arnold (1973), Tench (1996), and more recently, Wells (2006). In this paper, the tenets of the British School are presented following O'Connor and Arnold (1973) and Wells (2006).

The British School of intonation is characterized by a configurational analysis of the pitch contour, i.e. each intonation phrase is divided into a nuclear configuration and a prenuclear configuration. The nuclear configuration contains the only obligatory element of an intonation phrase, namely, the nucleus which consists of the last (or only) accented syllable. Any unaccented syllables after the nucleus make up the tail. The pre-nuclear configuration is optional and consists of a head and a pre-head. The head contains all the syllables from the first accent up to the syllable before the nucleus. The pre-head includes the unaccented syllables before the first accent. An example is provided in (1) for the sentence She can come on Monday which has two stressed syllables, marked with an asterisk, that are accented (i.e. produced with relevant pitch movement).

(1)

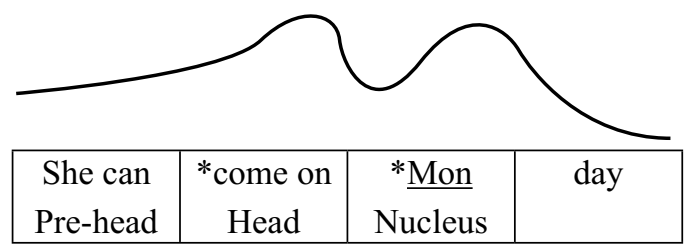

Furthermore, the British School of intonation describes the $\mathrm{F}_{0}$ contours by means of pitch movements and thus its inventory of tones is based on pitch trajectories, such as, rise, fall, fall-rise, etc. However, the tonal categories differ depending on their location on the

* eestebas@flog.uned.es 
intonation phrase. Thus, the tones associated to the nuclear syllable are different from those associated to the pre-nuclear ones. This is so because the nuclear tones have to account not only for the pitch movement on the last accented syllable but also for the pitch pattern till the end of the intonation phrase. Thus, whereas tones, such as rise, fall, fall-rise or rise-fall only occur in the nuclear position, other tones, such as high and low, are only associated to the pre-nuclear accents. The pitch contour in (1) shows a high pre-nuclear accent followed by a high-fall nuclear accent, transcribed with the diacritics presented in (2).

\section{(2) She can 'come on 'Monday.}

Even though the benefits of the British model for the teaching of intonation have been widely attested, this framework is difficult to be used in a distance learning environment where students have neither face-to-face tuition nor immediate feedback on their learning outcomes. One of the main problems of the British model in an autonomous learning context is that students find it difficult to grasp the alignment of pitchtrajectory tones to the segmental string and cannot read and interpret the annotation conventions easily. This is particularly difficult with nuclear tones which vary in form and alignment depending on the number of unaccented syllables in the tail.

Given the difficulties in using the British tradition conventions of intonational description in a distance learning setting, Estebas-Vilaplana (2009) considered the possibility of using a teaching methodology based on the other main tradition of intonational analysis, namely, the American School and in particular, one of its latest theories, i.e. the Autosegmental-Metrical approach (Pierrehumbert 1980) and the follow-up ToBI (Tone and Break Indices) system (Beckman/Hirschberg 1994).

The American School of intonation (Pike 1945; Wells 1945; Trager/Smith 1951; Liberman 1975; Leben 1976) differs from the British tradition in two important characteristics: 1) the way of describing tones and 2) the interpretation of the final pitch movements of the intonation phrase. Whereas the British School describes tones by means of their pitch trajectories, the American School represents intonation as a series of tone levels (or tonal targets), which in the latest theories, such as the Autosegmental-Metrical approach (Pierrehumbert 1980; Ladd 1996; Gussenhoven 2004; among others) or ToBI (Beckman/Hirshberg 1994; Beckman/Alam-Eyers 1997) are specified as H (high) or L (low). $\mathrm{H}$ and $\mathrm{L}$ tones can be associated to stressed syllables or to the edges of the intonation phrases. When the tones are associated with stressed syllables, they are marked with an asterisk. Thus, $\mathrm{H}^{*}$ and $\mathrm{L}^{*}$ indicate that a high pitch and a low pitch occur within an accented syllable. The final movements of a pitch contour are described by means of boundary tones which can be of two kinds depending on whether they signal the edge of a higher prosodic domain (the intonation phrase) or a lower prosodic domain (the intermediate phrase). The tones at the end of an intonation phrase are called boundary tones and are marked with \% (i.e. $\mathrm{L} \%$ and $\mathrm{H} \%$ ), whereas the tones at the end of an intermediate phrase are known as phrase accents and are signalled with the symbol - (i.e. L- and H-).

The tenets of the Autosegmental-Metrical approach and the ToBI system have been used to describe the intonation patterns of a great variety of languages. The great impact 
of this framework is due to a number of reasons, such as its concise tonal description tools, reduced to two tones, and the clear-cut location of such tones with respect to the segmental layer (tones are only associated to stressed syllables and to the end of phrases). Despite the several advantages of the Autosegmental-Metrical approach and the ToBI system, it has never been used for pedagogical purposes. When it comes to teaching the intonation of (especially) foreign languages, some of the pros, such as the reduced number of tones, may turn out to be a drawback since it is really difficult for untrained students to grasp the meaning of categories that look pretty much the same (e.g. $\mathrm{H}^{*}, \mathrm{~L}+\mathrm{H}^{*}, \mathrm{~L}^{*}+\mathrm{H}, \mathrm{H}^{*}+\mathrm{L}, \mathrm{L}+\mathrm{H}^{*}$, etc.). Thus, despite the great impact of the ToBI system on intonational modeling, the teaching and learning of English intonation have rarely benefitted from its insights and thus the only model that is still at stake is the British School.

Given the pros and cons of both traditions, Estebas-Vilaplana (2009) designed a new methodology for the teaching and learning of intonation with the aim of helping students who specifically work in a self-tuition context. The new model combines some of the conventions of both traditions. In short, the new proposal, called TL ToBI (Teaching and Learning ToBI) adopts the association conventions of the original ToBI with a reduced number of tonal entities and maintains the types of tunes and nuclear configurations of the British approach. A more thorough description of TL_ToBI proposal is included in the next section.

\subsection{TL_ToBI}

Students that learn intonation in a distance learning setting by means of TL_ToBI will first be presented with the audio input of the utterance along with a graphic representation which outlines the pitch contour in relation to the syllabic structure of the sentence. This is illustrated in (3). Each box stands for a syllable and the shaded boxes represent stressed syllables that have a relevant pitch movement and thus become accented. The overlapped representation of the pitch contour with the syllable division helps students to realize where exactly the relevant pitch movements take place in the segmental string.

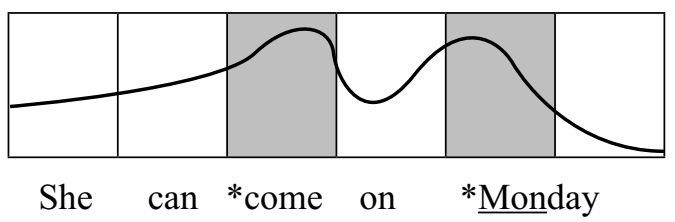

As far as the notation conventions are concerned, TL_ToBI presents four main differences with respect to the original ToBI system (Estebas-Vilaplana 2013): 1) the representation of the metrical information vs. the tonal information, 2) the number of pitch levels, 3) the number of phrases, and 4) the modeling of the nuclear and the pre-nuclear accents. 
The phonological categories proposed by the original ToBI system include not only tonal information ( $\mathrm{H}$ and $\mathrm{L}$ ) but also metrical information. Thus, for example, $\mathrm{H}^{*}$ indicates an $\mathrm{H}$ accent associated to a stressed syllable. $\mathrm{H}-$ and $\mathrm{H} \%$ signal the end of a minor and a major prosodic phrase respectively. In TL_ToBI, the metrical and the tonal information are kept apart so that the students concentrate on the characterization of the pitch movements alone. Thus, the metrical structure does not accompany the tone but is indicated in the segmental string by means of an asterisk, as illustrated in (3). By keeping the asterisk on the segmental string, students can clearly see the potential sites to associate a tone. Tones will then be located under the syllables marked with the asterisk and at the end of the sentence, as presented in (4). The syllable with the final accent is underlined. This shows the most prominent syllable of the contour and it also indicates that the tones located after this syllable are no longer pitch accents but correspond to categories that account for the tonal movements at the end of the phrase. When a phrase ends with an oxytone word, the pitch accent and the boundary tone are located on the same syllable.

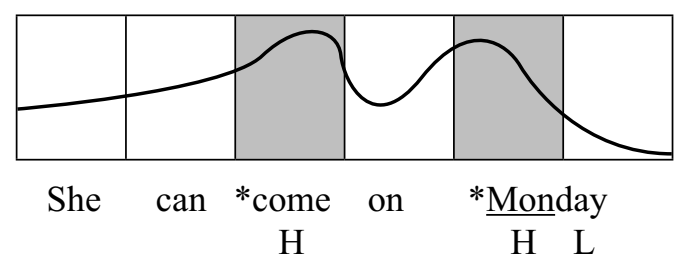

As far as pitch levels are concerned, the original ToBI system describes pitch movements by means two tones only ( $\mathrm{H}$ and $\mathrm{L}$ ). Whereas $\mathrm{L}$ tones usually correspond to a rather constant $\mathrm{F}_{0}, \mathrm{H}$ tones show more variation in their scaling and are sometimes downstepped $(! \mathrm{H})$ or upstepped $\left({ }_{i} \mathrm{H}\right)$, i.e. produced at a much lower or much higher $\mathrm{F}_{0}$ levels than a previous $\mathrm{H}$. Traditionally, downstep and upstep have been described as relational features since the presence of $! \mathrm{H}$ or ${ }_{i} \mathrm{H}$ seemed to depend on the scaling of the previous H. More recently, several studies, such as Vanrell (2006) for Catalan or Estebas-Vilaplana and Prieto (2008) for Spanish, have shown that in some languages differences in the scaling of $\mathrm{H}$ tones are contrastive and thus a three-tonal inventory (High, Mid, Low) has been incorporated in the system. A model of three tonal categories (H, M and L) was also presented in the work of Liberman (1975), which preceded Pierrehumbert's (1980) proposal of reducing the inventory into $\mathrm{H}$ and $\mathrm{L}$.

Within the British tradition, the presence of categories such as high-fall or low-fall corroborate the necessity to incorporate three levels of pitch description. For example, whereas a high-fall indicates a HL (high to low) movement, a low-fall stands for a ML (mid to low) trajectory. The new TL_ToBI proposal considers necessary to include a mid level tone (M) since its notation is much more transparent than !H. Thus, TL_ToBI uses three tonal categories: H, M, and L. These tones can occur both on stressed syllables and at the end of a pitch contour, as in (5). 
(5)

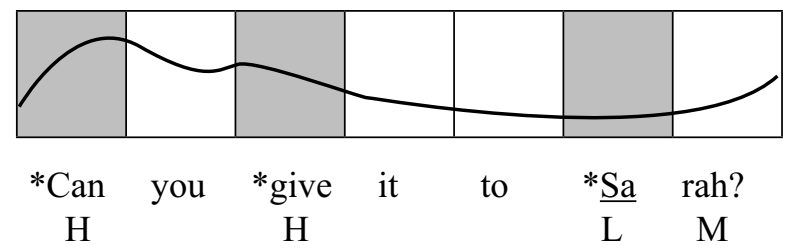

With respect to phrasing, even though the original ToBI system distinguishes two domains of phrasing, associated to different kinds of edge tones (boundary tones and phrase accents), the TL_ToBI proposal does not maintain the two-domain approach. Alternatively, students should only focus on the presence of a boundary, no matter whether it signals a major or a minor domain. For example, an enumeration is usually described as a series of intermediate phrases or minor domains ending with an Intonation Phrase or major domain. In the enumeration presented in (6), the end of each phrase is described in the same way, irrespective of whether it is a major or a minor phrase.

(6)

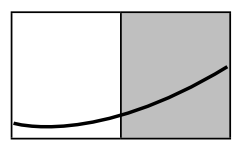

She's *tall,

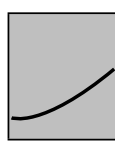

*blonde

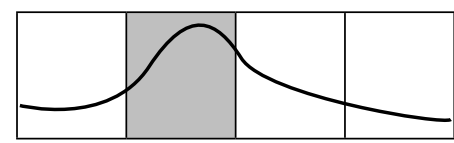

and

ful.

$\mathrm{L}$

As far as the modelling of the nuclear and pre-nuclear accents is concerned, TL_ ToBI maintains from the original ToBI system the idea that the same tones can be linked to both final and non-final accented syllables. Thus, contrary to the British tradition, there are no differences in the treatment of nuclear and pre-nuclear accents. However, relevant changes have been incorporated with respect to the original ToBI tonal entities. In ToBI, pitch accents can be both monotonal and bitonal whereas edge tones are only monotonal. In the TL_ToBI proposal, the reverse pattern is put forward since it includes monotonal pitch accents and boundary tones that can be both monotonal and bitonal.

As pointed out in Estebas-Vilaplana (2013), the idea to use only monotonal pitch accents is linked to the differences in the semantic load of the nuclear and the pre-nuclear parts of a pitch contour. Even though the pre-nuclear component obviously contributes to the creation of a tune, it is the nuclear configuration that is usually responsible for the final meaning of the sentence (Face 2007). According to this, the TL_ToBI methodology prompts students to focus on the pitch movements of the final part of the contour (last pitch accent and boundary tone), and hence reduces the detail in the description of pre-nuclear accents. The inventory of tones for both the final and the non-final accented syllables is $\mathrm{L}, \mathrm{M}$ and $\mathrm{H}$. 
In TL_ToBI, the inventory of boundary tones not only includes monotonal entities (L, M, H) but also bitonal tones ( $\mathrm{LH}, \mathrm{HL}$ ). Bitonal tones have been incorporated to account for complex final $\mathrm{F}_{0}$ movements, consisting of two tonal targets. In the original ToBI system, edge tones were only monotonal because complex $\mathrm{F}_{0}$ movements could be described by the combination of a phrase accent and a boundary tone. Since the new proposal only considers one level of phrasing, only one type of edge tones is put forward, namely, boundary tones. The presence of final complex movements creates the necessity of including boundary tones with two targets. Bitonal boundary tones have already been attested in other ToBI systems, such as Sp_ToBI (Estebas-Vilaplana/ Prieto 2008) for Spanish, and Cat_ToBI (Prieto et al. 2009) for Catalan. An example of a sentence with a final bitonal boundary tone is provided in (7), which illustrates a declarative sentence with a nuance of reservation.

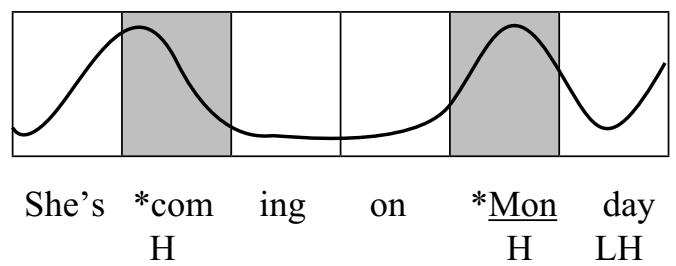

Despite the different annotation conventions, the combinations of tones used in TL ToBI are in line with the tonal configurations (nuclear and pre-nuclear) of the British tradition. With respect to the pre-nuclear configuration, only two tones were used (high and low), even though the model of O'Connor and Arnold (1973) includes other head tones, such as rising and falling, which also contribute to the meaning of the whole tune. The decision to reduce the number of head tones into two was to help distance learning students to concentrate on the nuclear configuration which tends to be much more relevant than the pre-nuclear one as far as the meaning of the sentence is concerned (Face 2007). The correspondences between the two systems are presented in Table 1, as presented in Estebas-Vilaplana (2013).

Table 1: TL_ToBI tonal combinations and their correspondences with the conventions of the British School

\begin{tabular}{|c|c|c|c|c|}
\hline British School & \multicolumn{2}{|c|}{ TL ToBI } & British School & TL_ToBI \\
\hline Nuclear tones & Pitch accents & Boundary tones & Pre-nuclear tones & Pitch accents \\
\hline High-fall & $\mathrm{H}$ & $\mathrm{L}$ & High & H \\
\hline Low-fall & $\mathrm{M}$ & $\mathrm{L}$ & Low & M or L \\
\hline High-rise & $\mathrm{M}$ & $\mathrm{H}$ & & \\
\hline Low-rise & $\mathrm{L}$ & $\mathrm{M}$ & & \\
\hline Mid-level & $\mathrm{M}$ & $\mathrm{M}$ & & \\
\hline Fall-rise & $\mathrm{H}$ & $\mathrm{L} \mathrm{H}$ & & \\
\hline Rise-fall & $\mathrm{L}$ & $\mathrm{H} \mathrm{L}$ & & \\
\hline
\end{tabular}


The second part of this paper explores the advantages and disadvantages of using TL_ToBI as an intonation teaching model in a distance learning environment and compares the intonation patterns of two groups of L2 students trained with different teaching methodologies, namely, the British School of intonational description and TL_ToBI. ${ }^{1}$

\section{THE EXPERIMENT}

The aim of this experiment is to compare the productions of English intonation by two groups of Spanish speakers who have been trained with different teaching methodologies, the British School and TL_ToBI, so as to so examine which model is more beneficial for acquiring some basic English intonation patterns in a distance learning environment.

\subsection{Informants}

The informants were 746 Spanish students of English phonetics registered in the English Pronunciation course offered at the Distance Learning University in Spain (UNED), as part of the Degree in English Studies, in the academic years 2012-2013 and 2013-2014. This course involves 150 hours of distance learning tuition distributed in four months. The aim of the course is to give students guidelines, tools and methodological resources for the autonomous learning of English pronunciation. The syllabus includes: 1) English Vowels, 2) English Consonants, 3) Combination of Sounds and Connected Speech Processes, 4) Stress and Rhythm, and 5) Focus and Intonation. 546 students were registered in 2012-2013 and 657 in 2013-2014. Only the students that sat for the final oral exam took part in this experiment, i.e. 334 students in 2012-2013 and 412 in 2013-2014. The age of the students was rather heterogeneous. This situation is typical of a distance learning environment which hosts students with very different backgrounds. The age of the students ranged from 21 to 74 years old in 2012-2013 and from 23 to 66 in 2013-2014. Students came from all over Spain being the biggest group from Madrid and its surroundings. The gender of the students was more balanced, with $54 \%$ of female students vs. $46 \%$ of male students in year $2012-2013$ and $57 \%$ of female students vs. $43 \%$ of male students in year 2013-2014. The students had at least a B1+ level of English according to the CEFR. Their first language was Spanish.

\subsection{Teaching Methodology and Corpus}

The students in year 2012-2013 learned English intonation according to the tenets of the British School, whereas those in year 2013-2014 followed the TL_ToBI methodology. The training materials used to present the two methodological approaches were specifically prepared by the teaching staff of the course so that they were as similar as possible. As stated before, the theoretical explanations of the British School were based on O'Connor and Arnold (1973) and Wells (2006) and included the division of

1 The results of this investigation have been presented at the Phonetics Teaching and Learning Conference 2015, London 5-7 August (see Estebas-Vilaplana 2015). 
the pitch pattern into a nuclear and a pre-nuclear configuration. The nuclear and pre-nuclear tones presented to the students are those specified in Table 1. As for the TL_ToBI system, the theoretical explanations were based on Estebas-Vilaplana (2009), which consisted in a simplification of the ToBI system, as presented in section 1.2. The tones used within this approach are also exhibited in Table 1.

The two models could not be tested simultaneously due to the limitations of the distance learning platforms since each course only allows for one virtual space where all students share the same teaching materials and participate in the same forums. The corpus of sentences and the teaching procedures presented in the two academic years were exactly the same, the only difference being the teaching methodology. For each course, students were presented with some theoretical explanations on English intonation following the premises of either the British School or the TL_ToBI model. The same examples and ear-training exercises, annotated with the conventions of one of the two frameworks, were used in the two courses.

The British School theoretical explanations and audio files were included in the virtual classroom of the English Pronunciation course. The TL ToBI materials were part of the book Teach Yourself English Pronunciation (Estebas-Vilaplana 2009) which also consists of an application with an interactive software. An example of the learning platform of this application is presented in Figure 1.

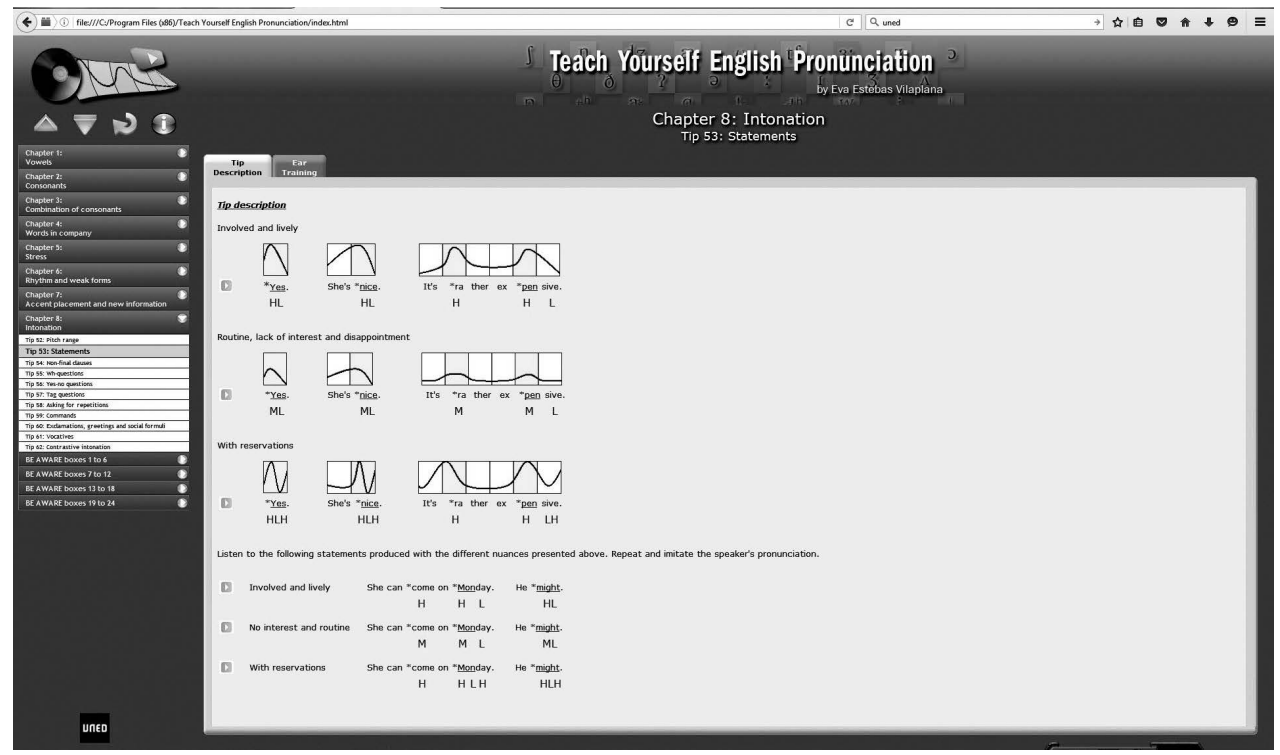

Figure 1: Illustration of the Teach Yourself English Pronunciation learning platform with some examples of the TL_ToBI teaching materials

For this particular investigation, four sentence types were taken into consideration: declaratives (D), yes-no questions ( $\mathrm{YN})$, wh-questions $(\mathrm{WH})$, and imperatives (I), 
produced both with neutral $(\mathrm{N})$ and marked intonation $(\mathrm{M})$. An example of each sentence type is presented in Table 2 with the British School and the TL_ToBI annotations.

All sentences analyzed in this study were made of one pre-nuclear pitch accent followed by a nuclear configuration which contained one pitch accent and a boundary tone. Each sentence type had the same segmental string for the neutral and the marked readings and they only differed in the intonation patterns. For each sentence type students listened to four examples presented in pairs, neutral (N) and marked (M). The ear-training exercises consisted of three listening activities of ten entries each in which the students had to identify, discriminate and reproduce the intonation patterns.

Table 2: English sentence types and examples presented with the annotation conventions of the British School and TL_ToBI

\begin{tabular}{|c|c|c|}
\hline Neutral declarative & She can 'come on 'Monday. & She can *come on * Monday. \\
\hline & & $\mathrm{H}$ \\
\hline $\begin{array}{l}\text { Marked declarative } \\
\text { (with reservations) }\end{array}$ & She can 'come on ${ }^{\vee}$ Monday. & She can *come on ${ }_{\mathrm{H}}^{*} \frac{\text { Monday. }}{\mathrm{H} \mathrm{L}} \mathrm{H}$ \\
\hline Neutral yes-no question & 'Are you , coming? & 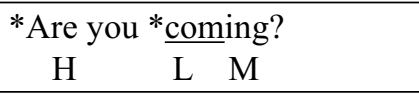 \\
\hline $\begin{array}{l}\text { Marked yes-no question } \\
\text { (confirmation seeking) }\end{array}$ & 'Are you 'coming? & *Are you * $\frac{\text { coming? }}{\mathrm{H}} \mathrm{H} \quad \mathrm{L}$ ? \\
\hline Neutral wh-question & 'What's your 'name? & ${ }_{\mathrm{H}}^{* \text { What's your }} \frac{{ }^{\text {name}}}{\mathrm{HL}}$ ? \\
\hline $\begin{array}{l}\text { Marked wh-question } \\
\text { (polite) }\end{array}$ & 'What's your , name? & $\begin{array}{c}* \text { What's your } \\
\text { H }\end{array}$ \\
\hline Neutral imperative & 'Don't touch it. & $\begin{array}{c}* \text { Don't * } \\
\text { H }\end{array}$ \\
\hline $\begin{array}{l}\text { Marked imperative } \\
\text { (warning) }\end{array}$ & 'Don't touch it. & $\begin{array}{l}\text { *Don't * touch it. } \\
\text { H }\end{array}$ \\
\hline
\end{tabular}

\subsection{Experimental Procedure}

The data was gathered as part of the English Pronunciation course final oral exam. Every year this exam is recorded by means of the E-oral application, which is a software designed at the UNED to do oral exams on-line (López et al. 2006). Students need to have a computer with a microphone and a webcam. Figure 2 shows an example of the E-oral application used in the on-line oral tests.

For the oral exam, students can see the questions on the screen. The exercises consist in reading a series of phonetic contrasts that include both segmental and suprasegmental features. Students can repeat the recording a maximum of three times and finally choose the sample they consider more appropriate and reject the other two. The examiner only assesses the selected version. The oral test is divided in three parts: 1) the production of English vowels, consonants and clusters, 2) the production of English 
stress, rhythm, focus and intonation patterns, and 3) the reading of a phonetic transcription. For this study, only the data on intonation was analyzed.

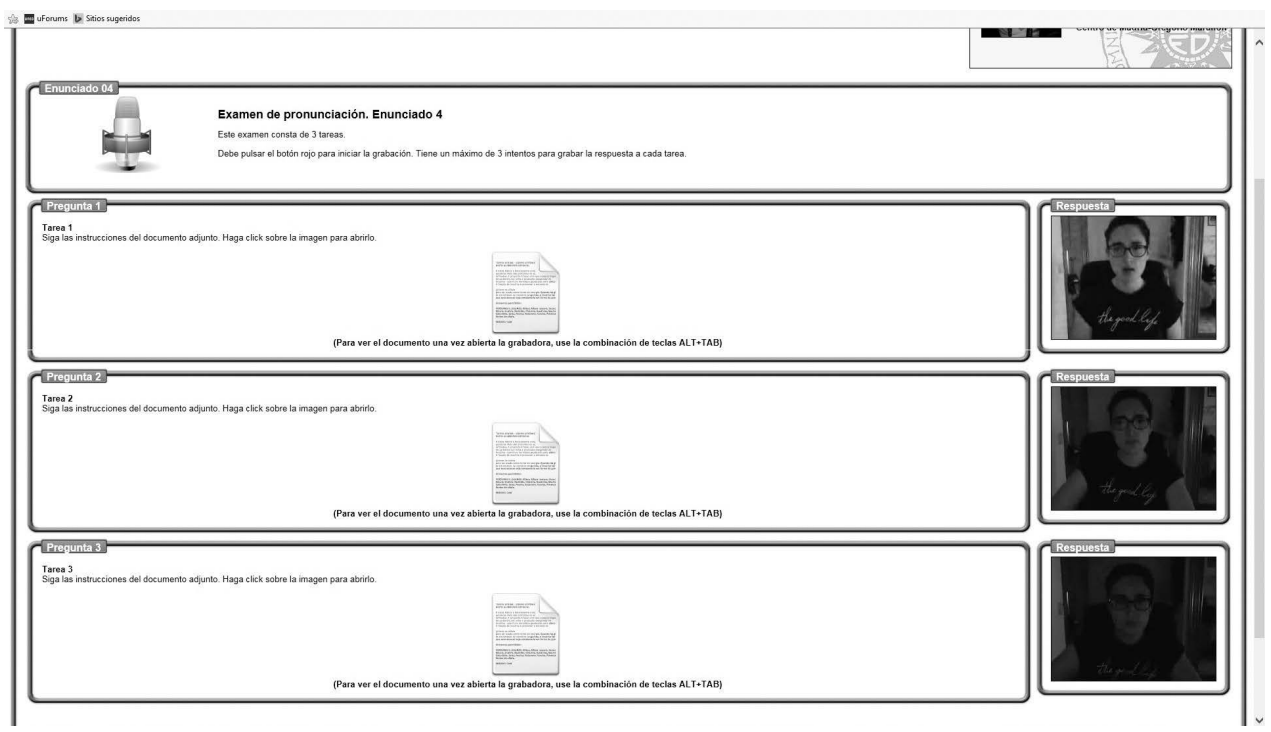

Figure 2: Image of the E-oral application used at the Distance Learning University in Spain (UNED) for on-line oral exams

There were seven models of oral tests which appeared randomly in the application. The types of questions were exactly the same in all models, the only difference being the data included in each question so that students could not know the precise words or sentences they were expected to produce. With respect to the intonation patterns, sentences were presented as in the teaching materials, that is, they were accompanied by the prosodic annotations used in each intonation model. In addition, for each sentence, the expected nuance (e.g. polite, warning, etc.) was also indicated. An example of the type of exercise is illustrated in (8) and (9) with the British and the TL_ToBI conventions respectively.

(8)

Read the following sentences with the intonation patterns used to convey the different meanings or nuances.

Statements

I 'hope you'like it. neutral

I 'hope you vike it. with reservations

Wh-questions

Which 'book will you 'buy? neutral

Which 'book will you ,buy? polite 
(9)

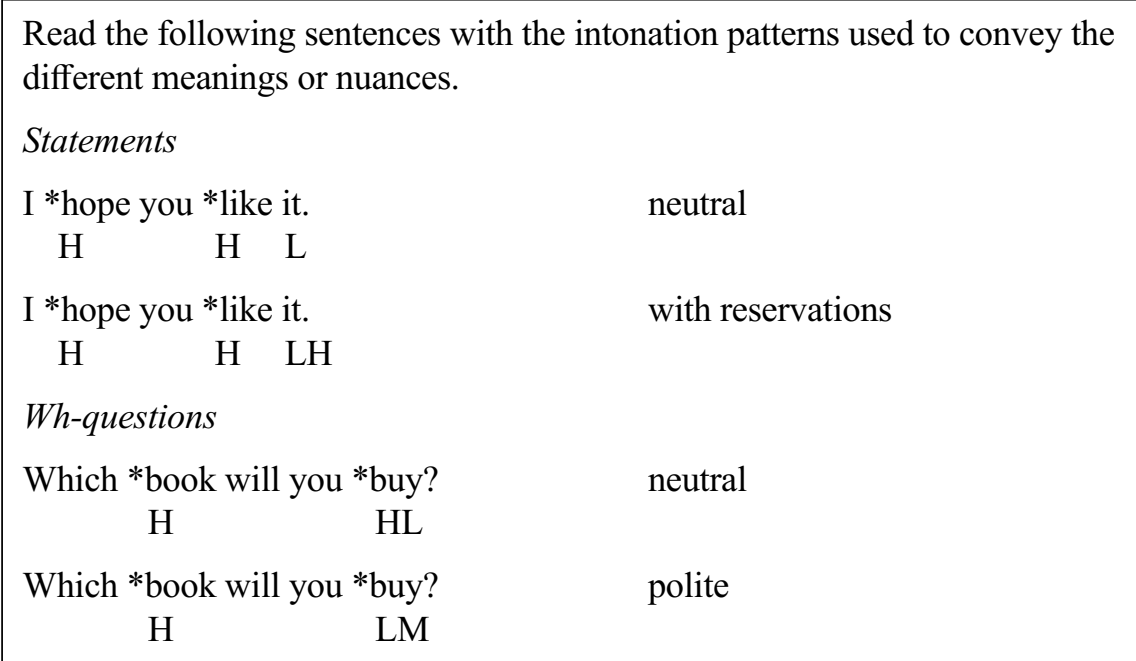

The recording of the final oral exam was done at the end of the course. Each student had to produce eight sentences as the ones presented in Table 2. A total of 5968 sentences were assessed, 2672 in year 2012-2013 and 3296 in year 2013-2014.

\section{DATA ANALYSIS}

The students' productions in the oral test were analyzed perceptually by three members of the teaching team, including the main lecturer and two backup tutors, one of them English. The three judges were the same in the two academic years and assessed the same sentence types in each year, even though the teaching methodology was different. For each sentence type they had to decide whether the productions of the Spanish students followed the expected English pitch patterns according to three positions: 1) the nuclear configuration, 2) the pre-nuclear accent, and 3) the whole tune.

Before assessing the productions, tutors were instructed about the expected differences and similarities between English and Spanish intonation for the various sentence types, so as they could better perceive cases of possible interference. The pitch configurations presented to the tutors for the two languages are exhibited in Table 3, which shows that the pre-nuclear accent is different for all sentence types. In the Spanish pre-nuclear configurations, the symbol $>$ indicates that there is a peak in the posttonic syllable. Thus, $\mathrm{L}>$ and $\mathrm{H}>$ stand for a low tone and a high tone respectively in the accented syllable with a peak in the post-accented one. These tones correspond to $\mathrm{L}^{*}+\mathrm{H}$ and $\mathrm{L}+>\mathrm{H}^{*}$ in the Spanish ToBI system (Sp_ToBI). For both languages, the nuclear configuration is the same in neutral and marked yes-no questions, in marked wh-questions and in marked imperatives. For each production, the assessments of the three teachers were contrasted. In case of disagreement, sentences were analyzed again by the three judges. 
Table 3: Differences $(\neq)$ and similarities $(=)$ in the pitch patterns of the pre-nuclear and nuclear configurations of various $\mathrm{E}(\mathrm{nglish})$ and $\mathrm{S}$ (panish) sentences. > indicates a peak in the post-tonic syllable

\begin{tabular}{|c|c|c|c|c|c|}
\hline Sentence types & Language & Pre-nuclear & & Nuclear & \\
\hline \multirow[t]{2}{*}{ N-D } & $\mathrm{E}$ & $\mathrm{H}$ & \multirow[t]{2}{*}{$\neq$} & $\mathrm{H} \mathrm{L}$ & \multirow[t]{2}{*}{$\neq$} \\
\hline & $\mathrm{S}$ & $\mathrm{H}>$ & & $\mathrm{L} \mathrm{L}$ & \\
\hline \multirow[t]{2}{*}{ M-D } & $\mathrm{E}$ & $\mathrm{H}$ & \multirow[t]{2}{*}{$\neq$} & $\mathrm{H} \mathrm{LH}$ & \multirow[t]{2}{*}{$\neq$} \\
\hline & $\mathrm{S}$ & $\mathrm{H}>$ & & $\mathrm{H} \mathrm{M}$ & \\
\hline \multirow[t]{2}{*}{ N-YN } & $\mathrm{E}$ & $\mathrm{H}$ & \multirow[t]{2}{*}{$\neq$} & $\mathrm{L} \mathrm{M}$ & \multirow[t]{2}{*}{$=$} \\
\hline & $\mathrm{S}$ & $\mathrm{L}>$ & & L M & \\
\hline \multirow[t]{2}{*}{ M-YN } & $E$ & $\mathrm{H}$ & \multirow[t]{2}{*}{$\neq$} & $\mathrm{H} \mathrm{L}$ & \multirow[t]{2}{*}{$=$} \\
\hline & $\mathrm{S}$ & $\mathrm{L}>$ & & $\mathrm{H} \mathrm{L}$ & \\
\hline \multirow[t]{2}{*}{ N-WH } & $\mathrm{E}$ & $\mathrm{H}$ & \multirow[t]{2}{*}{$\neq$} & $\mathrm{H} \mathrm{L}$ & \multirow[t]{2}{*}{$\neq$} \\
\hline & $\mathrm{S}$ & $\mathrm{H}>$ & & $\mathrm{L} \mathrm{L}$ & \\
\hline \multirow[t]{2}{*}{ M-WH } & $\mathrm{E}$ & $\mathrm{H}$ & \multirow[t]{2}{*}{$\neq$} & L M & \multirow[t]{2}{*}{$=$} \\
\hline & $\mathrm{S}$ & $\mathrm{H}>$ & & L M & \\
\hline \multirow[t]{2}{*}{ N-I } & $E$ & $\mathrm{H}$ & \multirow[t]{2}{*}{$\neq$} & M L & \multirow[t]{2}{*}{$\neq$} \\
\hline & $\mathrm{S}$ & $\mathrm{H}>$ & & $\mathrm{L} \mathrm{L}$ & \\
\hline \multirow[t]{2}{*}{ M-I } & $E$ & $\mathrm{H}$ & \multirow[t]{2}{*}{$\neq$} & $\mathrm{H} \mathrm{LH}$ & \multirow[t]{2}{*}{$=$} \\
\hline & $\mathrm{S}$ & $\mathrm{H}>$ & & $\mathrm{H} \mathrm{LH}$ & \\
\hline
\end{tabular}

\section{RESULTS}

The percentages of expected English intonation patterns produced by Spanish students after being trained with one of the two models, British School (BS) or TL_ToBI, are presented in Table 4 for the whole tune as well as for the nuclear and the pre-nuclear configurations. The results show that in all cases students trained with TL ToBI (412 students) produced more native-like intonation patterns than those instructed with the British model (334 students). Two-tailed t-tests comparing the data showed significant differences in all cases $(\mathrm{p}<0.01)$.

Table 4: Percentages (\%) of expected English pitch patterns produced by Spanish students trained with the British School (BS) and TL_ToBI

\begin{tabular}{|c|c|c|c|c|c|c|}
\cline { 2 - 7 } \multicolumn{1}{c|}{} & \multicolumn{2}{c|}{ Whole tune } & \multicolumn{2}{c|}{ Nuclear C. } & \multicolumn{2}{c|}{ Pre-nuclear C. } \\
\cline { 2 - 7 } \multicolumn{1}{c|}{} & BS & TL_ToBI & BS & TL_ToBI & BS & TL_ToBI \\
\hline$\%$ & 52.2 & 65.1 & 57.8 & 73.1 & 53.3 & 67.1 \\
\hline
\end{tabular}

The percentages of expected English intonation patterns according to sentence type are exhibited in Figure 3 for the overall tune. For all sentence types, the results show a higher percentage of native-like pitch patterns for those students trained with TL_ToBI than for those trained with the British system. Two-tailed t-tests presented significant differences in all cases $(\mathrm{p}<0.01)$. 


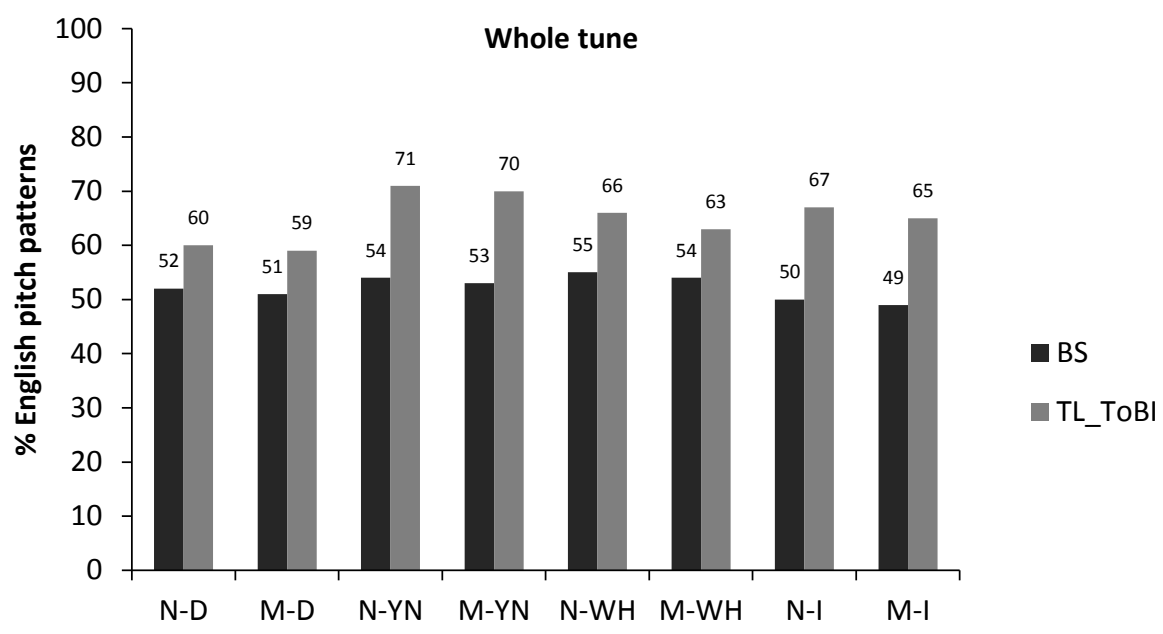

Figure 3. Percentage of English intonation patterns produced by Spanish speakers trained with the British School (BS) and TL_ToBI

Figure 4 displays the percentages of expected English intonation patterns for the nuclear configuration. As before, the results for all sentence types show that the pitch patterns are significantly better $(p<0.01)$ for those students who followed the TL_ToBI methodology than for those that were trained in line with the British framework.

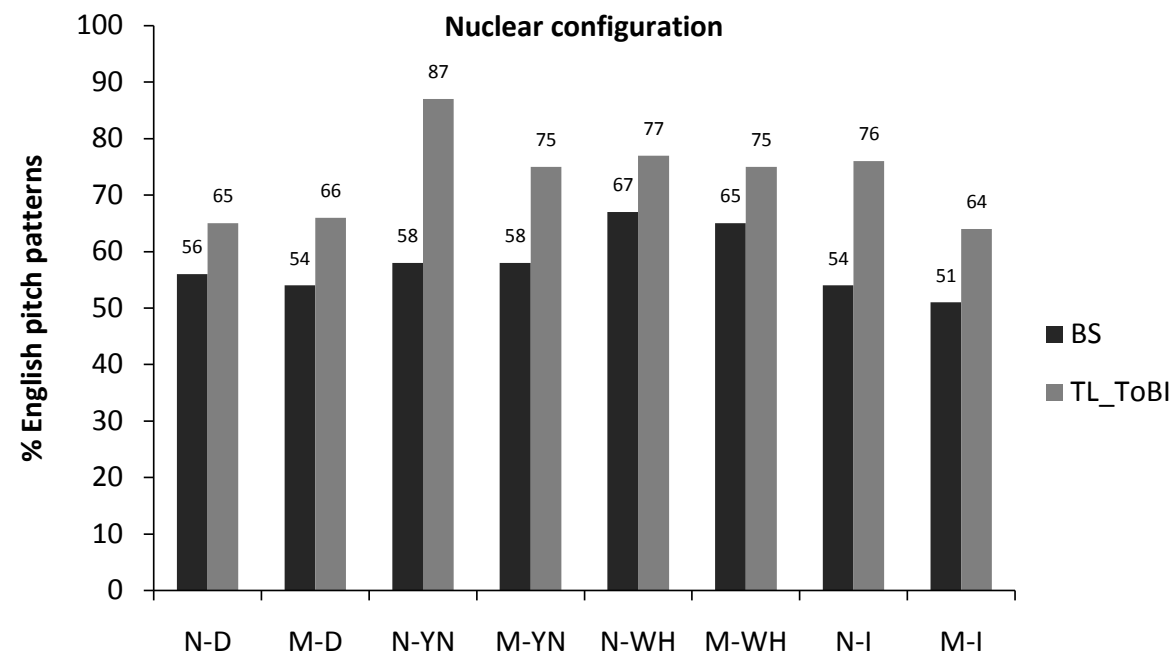

Figure 4. Percentage of English intonation patterns in the nuclear configuration produced by Spanish speakers trained with the British School (BS) and TL_ToBI 
Finally, Figure 5 shows the percentages of expected English intonation patterns for the pre-nuclear accent, which also present significantly better results $(\mathrm{p}<0.01)$ in all sentence types for the students trained with TL_ToBI. These findings suggest that a system based on visual aids and the association of tonal targets with the metrical structure has more benefits in the acquisition of L2 prosody in a distance learning environment.

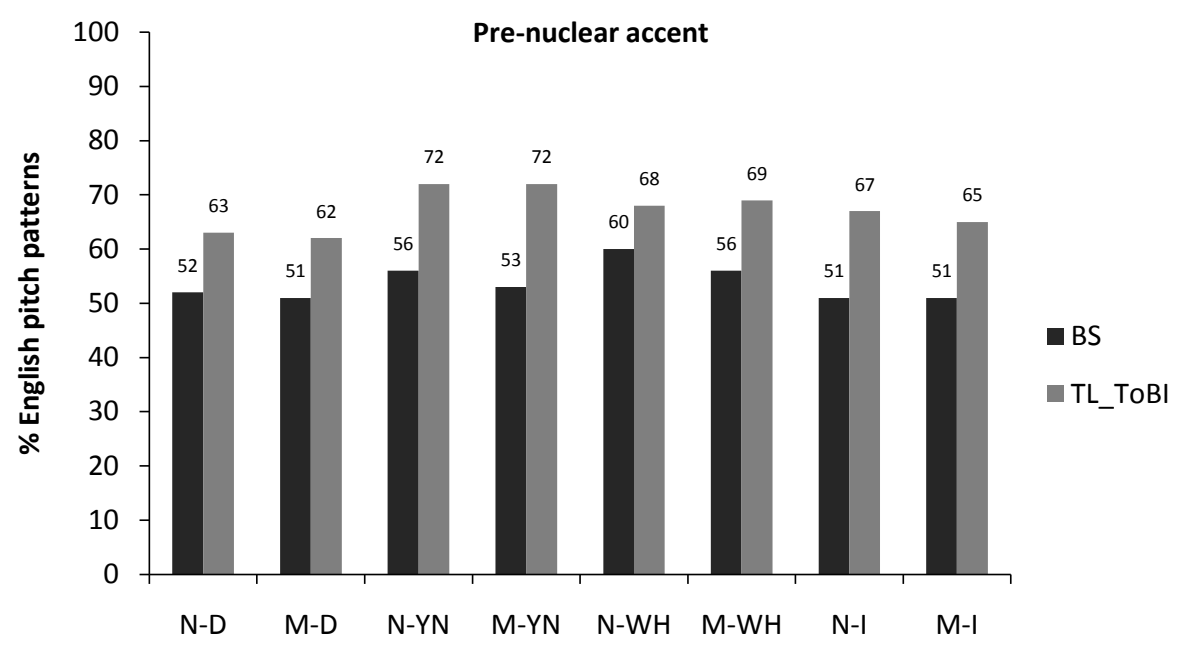

Figure 5. Percentage of English intonation patterns in the pre-nuclear accent produced by Spanish speakers trained with the British School (BS) and TL_ToBI

When the three graphs are compared, the percentage of native-like pitch patterns increases for the nuclear configuration variable, which shows better results than those of the pre-nuclear accent and the whole tune for all sentence types. The comparison between the results of the pre-nuclear accent and those of the whole tune presents very similar patterns. Two-paired t-tests showed non-significant differences in these cases $(p>0.01)$, suggesting that the cause of a foreign intonation is often derived from the unexpected production of the pre-nuclear configuration. These results indicate that even though L2 students produce the nuclear configuration of several sentence types with the expected pitch pattern, L1 speakers still judge those sentences as inaccurate, given the unexpected pronunciation of the pre-nuclear configuration. Thus, although the nuclear pattern has been shown to be the most important one to convey the meaning of a sentence (Face 2007), the pre-nuclear configuration should not be neglected in intonation teaching since it is the cause of a strong non-native accent effect.

Furthermore, in all Figures, the highest percentage of native-like pitch patterns is obtained in questions, with the highest score (over 80\%) in the nuclear configuration of neutral yes-no questions. This might be explained by the similarities in the final intonation of some question types in English and in Spanish, such as the final rise (LM) in neutral yes-no questions and in marked wh-questions or the high-fall (HL) in marked yes-no questions. 


\section{DISCUSSION AND CONCLUSIONS}

The teaching of intonation to L2 students has often been an arduous task due to both the difficulty in finding an appropriate methodology that helps students to grasp prosodic features easily and to the intrinsic ability of the students to perceive and produce the pitch patterns. It has been observed that students with musical skills tend to identify and reproduce the pitch contours more effortlessly than students with a minor musical talent (Barreiro/Estebas-Vilaplana/Soto 2005). Given the different degrees of innate capacity students have to assimilate the L2 prosody, it is crucial to use a teaching and learning methodology simple enough to reach all kinds of audiences. The autonomous learning of intonation in a distance learning environment enhances the idea of using straightforward techniques and notation conventions to facilitate the acquisition of the intonation of the main sentence types.

The British School of intonational description has been at the lead of English intonation teaching for almost a century. Its insights have been used both in specialized courses on English prosody and in L2 teaching materials aimed at a broader audience. Despite the enormous impact of the British School on the teaching and learning of English intonation, its tenets did not entirely work for autonomous learning, since students could not easily understand the link between the segmental structure and the intonation patterns. Similarly, despite the great impact of the ToBI systems for the prosodic annotation of a huge variety of languages, it has never been used for teaching and learning given its big number of entities sometimes used to show phonetic detail rather than phonological generalizations.

In this study, a new methodology for the teaching of English intonation to nonnative speakers (TL_ToBI) has been presented and compared with one of the traditional models for prosodic training, namely, the British School. TL_ToBI proposes an adaptation of the annotation conventions of the original ToBI system to account for the main types of tunes and nuclear configurations described within the British approach.

The results of this study have shown that students instructed with TL_ToBI produced more native-like intonation patterns than those that followed the British system, confirming the benefits of a methodology based on tonal targets and their explicit association to some parts of the segmental string. Despite the better results obtained with TL_ToBI, more work needs to be done to further improve the students' productions as well as to present them with a wider range of tunes and nuances. One of the measures that will be taken into account in future courses is to present students with the intonation patterns of the L1 along with those of the L2. A comparison between the L1 and the L2 intonation patterns can be a further step for a successful learning of the L2 prosody since students will be aware of the cross-linguistic differences and this might help them in their self-assessment and evaluation processes.

Studies on second language acquisition have shown that sometimes explicit knowledge on phonetic issues can be beneficial to improve L2 production accuracy (Piske/ Mackay/Flege 2001, Lord 2005, and Fullana 2006, among others). Similarly, the Noticing Hypothesis states that L2 learners cannot grasp the features of a language unless they notice them and that that noticing is the essential starting point for acquisition 
(Schmidt 1993, 2010). This paper has shown that, in the case of L2 intonation, not only explicit knowledge and noticing contribute to its proficiency but also different methodologies can play an important role on the results. This investigation has shown that a system based on tonal targets and their association to the metrical structure, such as TL_ToBI, has more benefits for the acquisition of the $\mathrm{L} 2$ intonation in a distance learning environment than an approach based on pitch trajectories, such as the British School. The workability of TL_ToBI in other settings, such as in a face-to-face classroom, is an issue for future research.

\section{References}

BARREIRO, Silvia/Eva ESTEBAS-VILAPLANA/Isabel SOTO (2005) "Teaching phonetics through singing and reciting." Proceedings of the Phonetics Teaching and Learning Conference 2005. London: UCL, 1-4.

BECKMAN, Mary/Gayle AYERS-ELAM (1997) Guidelines for ToBI labelling. http:// www.ling.ohio-state.edu/research/phonetics/E_ToBI/

BECKMAN, Mary/Julia HIRSCHBERG (1994) The ToBI annotation conventions. http://www.ling.ohio-state.edu/ tobi/ame_tobi/annotation_conventions.html

COUPER-KUHLEN, Elisabeth (1986) An introduction to English prosody. London: Edward Arnold.

CRUTTENDEN, Alan (1986) Intonation. Cambridge: Cambridge University Press.

CRYSTAL, David (1969) Prosodic systems and intonation in English. Cambridge: Cambridge University Press.

ESTEBAS-VILAPLANA, Eva (2009) Teach yourself English pronunciation: An interactive course for Spanish speakers. Madrid: UNED.

ESTEBAS-VILAPLANA, Eva (2013) "TL_ToBI: a new system for teaching and learning intonation." Proceedings of the Phonetics Teaching and Learning Conference 2013. London: UCL, 39-42.

ESTEBAS-VILAPLANA, Eva (2015) "The learning of English intonation by Spanish speakers in a distance education environment." In: J. Przedlacka/J. Maidment/M. Ashby (eds), Proceedings of the Phonetics Teaching and Learning Conference, UCL, London, 5-7 August 2015. London: Phonetics Teaching and Learning Conference, 39-43. http:// www.ucl.ac.uk/pals/study/cpd/cpd-courses/ptlc/proceedings_2015/PTLC2015.pdf

ESTEBAS-VILAPLANA, Eva/Pilar PRIETO (2008) "La notación prosódica del español: una revisión del Sp_ToBI." Estudios de Fonética Experimental XVII, 265-283.

FACE, Timothy L. (2007) "The role of intonational cues in the perception of declaratives and absolute interrogatives in Castilian Spanish." Estudios de Fonética Experimental XVI, 185-225.

FULLANA, Natalia (2006) "The development of English (FL) perception and production skills: starting age and exposure effects." In: C. Muñoz (ed.), Age and the rate of foreign language learning. Clevedon UK: Multilingual Matters, 41-64.

GIMSON, Alfred C. (1980) An Introduction to the Pronunciation of English. London: Edward Arnold. 
GUSSENHOVEN, Carlos (2004) The phonology of tone and intonation. Cambridge: Cambridge University Press.

KINGDON, Roger (1958) The Groundwork of English Intonation. London: Longmans, Green and Co.

LADD, Robert (1996) Intonational Phonology. Cambridge: Cambridge University Press.

LEBEN, William (1976) "The tones in English intonation." Linguistic Analysis 2, 69-107.

LIBERMAN, Mark (1975) The intonational system of English. Doctoral dissertation. Cambridge, MA: MIT.

LORD, Gillian (2005) "(How) can we teach second language pronunciation? On the effects on a Spanish phonetics course." Hispania 88/3, 557-567. http://dx.doi. org/10.2307/20063159

LÓPEZ, M. Eugenia/Laura ALBA JUEZ/Mónica ARAGONÉS/Beatriz MOLINA (2006) "E-oral: A hypermedia Web Application for English Language Oral Exams within a Distance Education Environment." In: Y. Song, C. Lu, R. Y. Lee (eds), Proceedings of SNPD 2006. Los Alamitos, California: IEE Computer Society, 343-48.

O'CONNOR, J. D./G. F. ARNOLD (1973) Intonation of colloquial English. London: Longman.

PALMER, Harold (1922) English intonation, with syntactic exercises. Cambridge: Heffer.

PIERREHUMBERT, Janet B. (1980) The phonetics and phonology of English intonation. Doctoral dissertation. Cambridge, MA: MIT.

PIKE, Kenneth L. (1945) The intonation of American English. Ann Arbor: University of Michigan Press.

PISKE, Thorsen/Ian R.A. MACKAY/James E. FLEGE (2001) "Factors affecting degree of foreign accent in an L2: a review." Journal of Phonetics 29/2, 191-215. http://dx.doi.org/10.1006/jpho.2001.0134

PRIETO, Pilar/Lourdes AGUILAR/Ignasi MASCARÓ/Francesc TORRES-TAMARIT, and Maria del Mar VANRELL BOSCH (2009) "L'etiquetatge prosòdic Cat_ ToBI". Estudios de Fonética Experimental 18, 287-309.

SCHMIDT, Richard (1993) "Awareness and second language acquisition." Annual Review of Applied Linguistics 13: 206-226. http://dx.doi.org/10.1017/ S0267190500002476

SCHMIDT, Richard (2010) "Attention, awareness and individual differences in language learning." In: W. M. Chan/S. Chi/K. N. Cin/J. Istanto/M. Nagami/J. W. Sew/T. Suthiwan/I. Walker (eds), Proceedings of CLaSIC 2010. Singapore: National University of Singapore, 721-737.

TENCH, Paul (1996) The intonation systems of English. London: Cassell.

TRAGER, George L./Henry L. SMITH (1951) An outline of English structure. Norman, OK: Battenburg Press.

WELLS, Rulon S. (1945) “The pitch phonemes of English." Language 21/1, 27-39.

WELLS, John (2006) English intonation: an introduction. Cambridge: Cambridge University Press. 


\section{Abstract \\ THE TEACHING AND LEARNING OF L2 ENGLISH INTONATION IN A DISTANCE EDUCATION ENVIRONMENT: TL_TOBI VS. THE TRADITIONAL MODELS}

The teaching of intonation to learners of a second language (L2) tends to be an arduous and often neglected task even in specialized phonetic classes. This difficulty generally increases in a distance learning environment where students have to approach prosodic issues in an autonomous way. This paper tests the advantages and disadvantages of using a new model to teach English intonation to Spanish speakers in a self-tuition context, called TL_ToBI (Teaching and Learning ToBI), and compares the benefits of this proposal with the traditional methodologies. Two groups of Spanish students of English phonetics in a distance learning environment took part in this study. Each group was trained with a different methodology: 1) the British School of intonation and 2) TL_ToBI, which involves an adaptation of the ToBI conventions for teaching purposes. The intonation of four sentence types was assessed: declarative, yes-no question, wh-question, and imperative, produced both with neutral and marked readings. The results showed that those speakers trained with TL_ToBI produced more native-like intonation patterns than those instructed with the other model. These findings suggest that a system based on tonal targets and their association to the metrical structure has more benefits for the acquisition of the L2 prosody in a distance learning setting.

Keywords: L2 intonation, distance learning, TL_ToBI, British School, English

Povzetek POUČEVANJE IN UČENJE INTONACIJE V ANGLEŠČINI KOT
DODATNEM JEZIKU V OKOLJU UČENJA NA DALJAVO:
TL_ToBI proti TRADICIONALNIM MODELOM

Poučevanje intonacije drugega jezika je naporna in pogosto spregledana naloga celo $\mathrm{v}$ razredih, specializiranih za fonetiko. Težavnost se še poveča $\mathrm{v}$ okolju učenja na daljavo, kjer študenti spoznavajo prozodične vsebine samostojno. Članek obravnava prednosti in pomanjkljivosti rabe novega modela za poučevanje angleške intonacije španskih govorcev v procesu samostojnega učenja, imenovanega TL_ToBI, ter primerja njegove koristi s tradicionalnimi metodami. V študiji sta sodelovali dve skupini španskih študentov angleščine na daljavo. Vsaka skupina se je učila angleško intonacijo po drugi metodi: 1) britanski šoli intonacije in 2) TL_Tobi metodi, ki je pouku prilagojen model ToBI. Presojali smo intonacijo v štirih vrstah povedi: trdilnih, da/ne vprašanjih, $\mathrm{k} / \check{\mathrm{c}}$ vprašanjih in velelnikih, ki so bile izrečene $\mathrm{v}$ nezaznamovanem in zaznamovanem kontekstu. Rezultati so pokazali, da so študenti, ki so se učili intonacijo po metodi TL_ToBI, uporabljali intonacijske vzorce, ki so bolj 
podobni intonacijskim vzorcem angleških domačih govorcev, kot študenti, ki so se učili po drugi metodologiji. Te ugotovitve kažejo, da ima metoda, ki temelji na tonskih ciljih in njihovi povezavi z metrično strukturo, več koristi za usvajanje intonacije dodatnega jezika v okolju učenja na daljavo.

Ključne besede: intonacija dodatnega jezika, učenje na daljavo, TL_ToBI, britanska šola, angleščina 